\title{
Mushrooms as functional foods
}

\author{
Győrfi, J. \\ Corvinus University of Budapest, Faculty of Horticultural Science, \\ Department of Vegetable and Mushroom Growing (gomba@uni-corvinus.hu)
}

\begin{abstract}
Summary: In this study I compared the nutritional composition of the commonly consumed fruits and vegetables with three of the most important cultivated mushrooms: white button mushroom (Agaricus bisporus LANGE/IMBACH), oyster mushroom (Pleurotus spp. JACQ. P. KUMM.) and shiitake (Lentinula edodes BERKELY/PEGLER). I compared the energy content and some mineral values (sodium, potassium, calcium, magnesium and selenium), as these play a major role in the nutritional value of mushrooms. The focus was on the vitamin B group and the vitamin D content in mushrooms, which is especially important due to the fact that fruits and vegetables do not contain this vitamin.

Nowadays one of the main research and experimental topic is finding possible ways for enhancing the vitamin D content in cultivated mushrooms by UV-light. The Corvinus University of Budapest is running a project in this research area as well.

Based on the data presented in this study we can say that mushrooms and therefore the cultivated mushrooms have an honourable place within the group of functional foods.
\end{abstract}

Key words: functional foods, cultivated mushrooms (white button mushroom, oyster mushroom, shiitake), minerals, vitamin B group, vitamin D

\section{Introduction}

The category functional foods $(\mathrm{FOSHU}=$ foods for specified health uses) was first introduced in the middle of the 1980's in Japan and in 1992 functional foods' was set as an act into the regulatory system (In: Cheung, 2008).

According to Japan's Nutrition Improvement Act, functional foods have to meet the following demands: consumption of this food must improve the health condition, its different components must have beneficial effect on the health and this should be proved by exact analysis, moreover the ingredients of this food must be of natural origin (Shimizu, 2003).

Mushrooms constitute the second largest group in the living world after the group of insects. There are approximately 1,5 millions of fungi all over the world (Hawksworth, 2001). Around 120000 species have been identified until now and of this amount 14000 are the macrofungus. The macrofungus have a distinctive fruit body, large enough to be seen with eye and to be picked by hand (Chang-Miles, 1992). Around 3000 species are edible and among this group there are 700 species with some known medicinal effects. The characteristics of some species are still partially or completely unknown and among them approximately 1400 species are more or less poisonous. „Fly agaric" (Amanita muscaria) or tale mushroom has psychoactive properties, while the death cap (Amanita phalloides) is extremely poisonous.

In the past centuries, people from different parts of the world had a very different view on mushrooms. In the ancient times the mushrooms were called the food of the Gods. The Pharaohs in the ancient Egypt were consuming mushrooms not only because of their special taste but because of the magical (hallucinogen) characteristics too. The ancient Greeks looked at mushrooms as providers of physical and mental power, while the Chinese put forward the mushrooms'health benefits.

Even the experts have underestimated the nutrient value of edible mushrooms. In the past decades, experiments have proved that the nutritional value of mushrooms is higher than of fruits and vegetables (Lelley-Vetter, 2004; Lelley-Vetter, 2005; Vetter et al., 2005).

According to the results of various experiments the value of the edible mushrooms are determined by following generally valid characteristics:

- low energy level;

- very low sodium concentration;

- high content of some minerals (potassium, calcium);

- high content of some trace elements, especially selenium;

- high content of several vitamins, mainly vitamin B group and vitamin $\mathrm{D}_{2}$.

In the comparison I included three species of the most important mushrooms cultivated in our country and the world: Agaricus bisporus $=$ white button mushroom (Figure 1), Pleurotus spp. = oyster mushroom (Figure 2) and Lentinula edodes $=$ shiitake (Figure 3 ). I have selected some of the most commonly consumed vegetables and fruits in Hungary to compare the content of energy, main minerals, vitamin B group and vitamin D. The main source for the data of the nutritional composition of fruits and vegetables are from Biró-Lindner (1999) and the contents of different mushrooms are from Vetter (1990, 1994 and 2000). 


\section{Energy content of mushrooms}

The energy content of edible mushrooms is generally low, which allows them to be used in low-energy diets (In: Cheung, 2008).

The daily requirement of energy for adults comes up to approx. $1800-3100 \mathrm{kcal}$.

A serving of $100 \mathrm{~g}$ fresh edible mushrooms provides only $1,4-1,6 \%$ of the daily energy requirement for adults (Table 1).

Table 1. Average energy kJ (kcal) content in $100 \mathrm{~g}$ vegetables, fruits and mushrooms (fresh)

\begin{tabular}{|c|c|c|c|}
\hline \multicolumn{4}{|c|}{ Average energy $\mathrm{kJ}$ (kcal) content in $\mathbf{1 0 0} \mathrm{g}$ vegetable and fruit (fresh) } \\
\hline \multicolumn{2}{|l|}{ Vegetables } & \multicolumn{2}{|c|}{ Fruits } \\
\hline Name & & Name & \\
\hline cabbage & $134(32)$ & apple & $130(31)$ \\
\hline carrot & $168(40)$ & apricot & $202(48)$ \\
\hline cauliflower & $126(30)$ & banana & 441(105) \\
\hline celeriac & $121(29)$ & grape & $328(78)$ \\
\hline cucumber & $50(12)$ & grapefruit & $151(36)$ \\
\hline green beans & $172(41)$ & lemon & $113(27)$ \\
\hline green peas & $378(90)$ & orange & $172(41)$ \\
\hline green pepper & $84(20)$ & peach & $172(41)$ \\
\hline kohlrabi & $164(39)$ & pear & $218(52)$ \\
\hline lettuce & $71(17)$ & plum & $244(58)$ \\
\hline spinach & $84(20)$ & raspberry & $122(29)$ \\
\hline tomato & $97(23)$ & sour cherry & $218(52)$ \\
\hline water melon & $122(29)$ & strawberry & $147(35)$ \\
\hline \multicolumn{4}{|c|}{ Average energy kJ (kcal) content in $100 \mathrm{~g}$ mushrooms (fresh) } \\
\hline white button mushroom & $168(40)$ & & \\
\hline oyster mushroom & $164(39)$ & & \\
\hline shiitake & $148(35)$ & & \\
\hline
\end{tabular}

Table 2. Average sodium and potassium content $(\mathrm{mg})$ in $100 \mathrm{~g}$ vegetables, fruits and mushrooms (fresh)

\begin{tabular}{|c|c|c|c|c|c|}
\hline \multicolumn{6}{|c|}{ Average content (mg) in $\mathbf{1 0 0} \mathrm{g}$ vegetables and fruits (fresh) } \\
\hline \multicolumn{3}{|c|}{ Vegetables } & \multicolumn{3}{|c|}{ Fruits } \\
\hline Name & Sodium & Potassium & Name & Sodium & Potassium \\
\hline cabbage & 23,0 & 216,0 & apple & 2,0 & 112,0 \\
\hline carrot & 70,0 & 360,0 & apricot & 6,1 & 226 \\
\hline cauliflower & 11,0 & 175,0 & banana & 22,0 & 500,0 \\
\hline celeriac & 100,0 & 370,0 & grape & 2,3 & 195,0 \\
\hline cucumber & 7,0 & 150,0 & grapefruit & - & - \\
\hline green beans & 1,0 & 229,0 & lemon & 4,3 & 275,0 \\
\hline green peas & 8,0 & 325,0 & orange & 2,6 & 255,0 \\
\hline green pepper & 4,0 & 160,0 & peach & 1,7 & 183,0 \\
\hline kohlrabi & 26,0 & 300,0 & pear & 2,3 & 100,0 \\
\hline lettuce & 16,0 & 261,0 & plum & 3,9 & 240,0 \\
\hline spinach & 24,0 & 526,0 & raspberry & 3,9 & 172,0 \\
\hline tomato & 5,0 & 240,0 & sour cherry & 4,7 & 186,0 \\
\hline water melon & 4,9 & 147,0 & strawberry & 4,6 & 145,0 \\
\hline \multicolumn{6}{|c|}{ Average content (mg) in $100 \mathrm{~g}$ mushrooms (fresh) } \\
\hline white button mushroom & 5,0 & 510,0 & & & \\
\hline oyster mushroom & 2,0 & 340,0 & & & \\
\hline shiitake & 2,0 & 250,0 & & & \\
\hline
\end{tabular}

\section{Minerals in mushrooms}

Cultivated mushrooms are good source of minerals. The fruiting bodies of the mushrooms - while heaving a low sodium level - contain high amounts of potassium, which is one of the most important mineral in human nutrition. The sodium content of different vegetables and fruits, furthermore mushrooms can be found in Table 2 .

Potassium is mainly supplied by vegetables, fruits, meat and fish. Mushrooms usually contain more potassium than most fruits and vegetables. Mushrooms, like white button mushroom usually contain more potassium than most fruits and vegetables (except spinach and banana) (Table 2).

The daily requirement of sodium for adults comes up to approx. $550 \mathrm{mg}$.

$100 \mathrm{~g}$ fresh mushrooms cover only $0,4-0,9 \%$ of daily sodium demand.

The daily requirement of potassium for adults is about $2000 \mathrm{mg}$, about $100 \mathrm{~g}$ fresh mushrooms cover $12,5-25,5 \%$ of the daily potassium demand.

Calcium - as well as being the most abundant mineral in the human body - provides the structure for our teeth and bones.

The daily requirement of calcium for adults comes up to approx. $1000-1200 \mathrm{mg}$.

$100 \mathrm{~g}$ of mushrooms contain $60-80 \mathrm{mg}$ of calcium, $5,5-7,5 \%$ of the daily demand (Table 3 ).

Magnesium is essential for good health; it helps to maintain normal muscle and nerve function. Magnesium keeps heart rhythm steady, supports a healthy immune system and keeps the bone structure.

The daily requirement of magnesium for adults comes up to approx. 300-400 mg.

$100 \mathrm{~g}$ of fresh mushrooms contain 15-16 mg of magnesium, $4,3-4,6 \%$ of the daily demand (Table 3.)

In the past two decades, the importance of selenium in human health was recognized. This mineral works as an antioxidant, protecting body cells from damage that might lead to heart and cancer diseases.

According to Bíró (2004) the daily intake of selenium should be 30-70 $\mu \mathrm{g}$. The main sources of selenium are meat, fish and eggs. Most of fruits and vegetables contain less than $1,0 \mu \mathrm{g} / 100 \mathrm{~g}$ selenium (Morris-Levander, 1970). The exceptions are garlic and various mushroom types. Mushrooms are one of the richest, natural sources of selenium. Selenium content in Agaricus bisporus varies dramatically (Table 4). This derives from the differences in the ingredients of compost. The white button mushroom extracts selenium from compost very well. Many experiments prove that white mushroom compost derived from wheat straw that grows in selenium-rich soil, produces fruiting bodies with higher amount of selenium, that those compost which contain wheat straw grown in selenium-poor areas. Agaricus bisporus can absorb more selenium therefore we can supplement the compost and the casing soil by different selenium 
Table 3. Average calcium and magnesium content $(\mu \mathrm{g})$ in $100 \mathrm{~g}$ vegetables, fruits and mushrooms (fresh)

\begin{tabular}{|c|c|c|c|c|c|}
\hline \multicolumn{6}{|c|}{ Average content (mg) in $\mathbf{1 0 0} \mathrm{g}$ vegetables and fruits (fresh) } \\
\hline \multicolumn{3}{|c|}{ Vegetables } & \multicolumn{3}{|c|}{ Fruits } \\
\hline Name & Calcium & Magnesium & Name & Calcium & Magnesium \\
\hline cabbage & 33,0 & 20,0 & apple & 5,5 & 6,0 \\
\hline carrot & 28,0 & 35,0 & apricot & 13,8 & 14,0 \\
\hline cauliflower & 26,0 & 21,0 & banana & 110,0 & 60,0 \\
\hline celeriac & 34,0 & 60,0 & grape & 28,2 & 14,0 \\
\hline cucumber & 18,0 & 16,0 & grapefruit & - & - \\
\hline green beans & 32,0 & 16,0 & lemon & 14,0 & 20,0 \\
\hline green peas & 41,0 & 42,0 & orange & 43,8 & 22,0 \\
\hline green pepper & 14,0 & 12,0 & peach & 5,7 & 10,0 \\
\hline kohlrabi & 43,0 & 24,0 & pear & 15,7 & 10,0 \\
\hline lettuce & 28,0 & 19,0 & plum & 16,0 & 16,0 \\
\hline spinach & 133,0 & 53,0 & raspberry & 27,3 & 24,0 \\
\hline tomato & 9,0 & 7,0 & sour cherry & 31,3 & 15,0 \\
\hline water melon & 19,4 & 15,0 & strawberry & 28,1 & 18,0 \\
\hline \multicolumn{6}{|c|}{ Average content (mg) in 100 g mushrooms (fresh) } \\
\hline $\begin{array}{l}\text { white button } \\
\text { mushroom }\end{array}$ & 80,0 & 15,0 & & & \\
\hline $\begin{array}{l}\text { oyster } \\
\text { mushroom }\end{array}$ & 70,0 & 16,0 & & & \\
\hline shiitake & 60 & 16,0 & & & \\
\hline
\end{tabular}

compounds (Vetter-Lelley, 2004; Fehérváry-Póczik et al., 2005). White button mushroom supplemented with selenium fully corresponds to functional food requirements.

The daily requirement of selenium for adults is around 30 to $70 \mu \mathrm{g}$. $100 \mathrm{~g}$ fresh mushrooms contain 4-32 $\mu \mathrm{g}$ of selenium, $8-64 \%$ of the daily requirement.

Table 4. Average selenium content $(\mu \mathrm{g})$ in $100 \mathrm{~g}$ vegetables, fruits and mushrooms (fresh)

\begin{tabular}{|c|c|c|c|}
\hline \multicolumn{4}{|c|}{ Average selenium content ( $\mu \mathrm{g})$ in $100 \mathrm{~g}$ vegetable and fruit (fresh) } \\
\hline \multicolumn{2}{|l|}{ Vegetables } & \multicolumn{2}{|c|}{ Fruits } \\
\hline Name & Selenium & Name & Selenium \\
\hline cabbage & 2,2 & apple & 0,3 \\
\hline carrot & 2,2 & apricot & 0,3 \\
\hline cauliflower & 0,6 & banana & 1,0 \\
\hline garlic & 27,6 & grape & 0,3 \\
\hline green beans & 0,6 & lemon & 0,0 \\
\hline green pepper & 0,6 & orange & 1,4 \\
\hline spinach & 1,0 & peach & 0,4 \\
\hline tomato & 0,5 & pear & 0,6 \\
\hline \multicolumn{4}{|c|}{ Average content $(\mu \mathrm{g})$ in $100 \mathrm{~g}$ mushrooms (fresh) } \\
\hline white button mushroom & $14,0-32,0$ & & \\
\hline oyster mushroom & 15,0 & & \\
\hline shiitake & 4,0 & & \\
\hline
\end{tabular}

\section{Group of vitamin B}

Vitamin B is the global name given to a number of related chemicals. All the B vitamins are water soluble. They work together to help break down carbohydrates into glucose, metabolise facts and protein and ensure the correct functioning of the central nervous system (www. shoppingtrolley. net/vitamin-guide. shtml. 2010.04.17).

Cultivated mushrooms are a rather good source of several vitamins, such as thiamin $\left(\mathrm{B}_{1}\right)$, riboflavin (vitamin $\mathrm{B}_{2}$ ), niacin or nicotinic acid (vitamin $\mathrm{B}_{3}$ ), pantothenic acid (vitamin $\mathrm{B}_{5}$ ) and folic acid (vitamin $\mathrm{B}_{9}$ ).

Vitamin $\mathbf{B}_{1}$ (thiamin) is mainly supplied by wholemeal bread, liver, bean, pea and yeast.

A deficiency of $\mathrm{B}_{1}$ can lead to beriberi, a disease of the nervous system. Thiamin content in mushrooms is quite low, ranging from 40 to $60 \mu \mathrm{g} / 100$ grams in fresh fruit body. Most vegetable's and fruit's thiamine content is similar to mushrooms except green peas, green beans, tomato and banana (Table 5).

The daily requirement of thiamin for adults is $1000-1300 \mu \mathrm{g}$.

About $100 \mathrm{~g}$ fresh mushrooms cover $3,5-5,2 \%$ of the daily thiamine demand.

Vitamin $\mathbf{B}_{\mathbf{2}}$ (riboflavin) helps to maintain healthy red blood cells and promotes good vision and healthy skin. Liver, yeast, milk, meat and fish are rich in vitamin $\mathrm{B}_{2}$.

The vitamin $\mathrm{B}_{2}$ content in mushrooms is higher than that generally found in vegetables or fruits (except spinach and green beans) as shown in Table 5 .

The daily requirement of vitamin $\mathrm{B}_{2}$ for adults comes up to approx. $1200-1500 \mu \mathrm{g}$.

About $100 \mathrm{~g}$ fresh mushrooms cover $8,0-20,0 \%$ of the daily riboflavin demand.

Table 5 Average thiamine and riboflavin content $(\mu \mathrm{g})$ in $100 \mathrm{~g}$ vegetables, fruits and mushrooms (fresh)

\begin{tabular}{|c|c|c|c|c|c|}
\hline \multicolumn{6}{|c|}{ Average content $(\boldsymbol{\mu g})$ in $\mathbf{1 0 0} \mathrm{g}$ vegetables and fruits (fresh) } \\
\hline \multicolumn{3}{|c|}{ Vegetables } & \multicolumn{3}{|c|}{ Fruits } \\
\hline Name & \begin{tabular}{|c|} 
Thiamine \\
$\left(\mathbf{B}_{1}\right)$
\end{tabular} & $\begin{array}{c}\text { Riboflavin } \\
\left(\mathrm{B}_{2}\right)\end{array}$ & Name & \begin{tabular}{|c|} 
Thiamine \\
$\left(\mathrm{B}_{1}\right)$
\end{tabular} & $\begin{array}{c}\text { Riboflavin } \\
\left(\mathrm{B}_{2}\right)\end{array}$ \\
\hline cabbage & 40 & 60 & apple & 50 & 50 \\
\hline carrot & 50 & 50 & apricot & 20 & 30 \\
\hline cauliflower & 60 & 100 & banana & 160 & 80 \\
\hline celeriac & 40 & 75 & grape & 50 & 50 \\
\hline cucumber & 60 & 50 & grapefruit & 40 & 20 \\
\hline green beans & 200 & 200 & lemon & 60 & 20 \\
\hline green peas & 200 & 150 & orange & 70 & 40 \\
\hline green pepper & 50 & 30 & peach & 20 & 20 \\
\hline kohlrabi & 50 & 50 & pear & 30 & 30 \\
\hline lettuce & 60 & 100 & plum & 50 & 20 \\
\hline spinach & 80 & 200 & raspberry & 20 & 30 \\
\hline tomato & 100 & 60 & sour cherry & 50 & 20 \\
\hline water melon & 40 & 20 & strawberry & 30 & 70 \\
\hline \multicolumn{6}{|c|}{ Average content $(\mu \mathrm{g})$ in $100 \mathrm{~g}$ mushrooms (fresh) } \\
\hline $\begin{array}{l}\text { white button } \\
\text { mushroom }\end{array}$ & 60 & 130 & & & \\
\hline $\begin{array}{l}\text { oyster } \\
\text { mushroom }\end{array}$ & 40 & 110 & & & \\
\hline shiitake & 60 & 270 & & & \\
\hline
\end{tabular}


Vitamin $\mathbf{B}_{\mathbf{3}}$ (niacin) helps to control the release of energy from protein, fat and carbohydrate, which promotes the functioning of the digestive and nervous system. The main direct sources of $\mathrm{B}_{3}$ vitamin in the diet include meat and cereals. Deficiency in $\mathrm{B}_{3}$ can lead to a disease called pellagra, whose main symptoms include dementia, skin and sleep problems. It is virtually unheard in the Western World, although still occurs in some parts of China, Africa and India.

Cultivated mushrooms are very rich in niacin: the content varies from 1 100-5 $200 \mu \mathrm{g} / 100 \mathrm{~g}$ fresh mushrooms (Table 6).

The daily requirement of vitamin $\mathrm{B}_{3}$ for adults is around 13 000-17 $000 \mu \mathrm{g}$.

About $100 \mathrm{~g}$ fresh mushrooms cover 7,5-35\% of the daily niacin demand (Figure 6).

Vitamin $\mathbf{B}_{5}$ (pantothenic acid) occurs naturally in mushrooms. It plays a numerous essential metabolic roles in the human body, including providing assistance with the production of hormones.

The daily requirement of panthotenic acid for adults is $6000 \mu \mathrm{g}$.

$100 \mathrm{~g}$ serving of mushrooms cover $8,5-30 \%$ of the recommended daily dietary intake of pantothenic acid (Table 6).

Table 6. Average niacin and pantothenic acid content $(\mu \mathrm{g})$ in $100 \mathrm{~g}$ vegetables, fruits and mushrooms (fresh)

\begin{tabular}{|c|c|c|c|c|c|}
\hline \multicolumn{6}{|c|}{ Average content $(\mu \mathrm{g})$ in $100 \mathrm{~g}$ vegetables and fruits (fresh) } \\
\hline \multicolumn{3}{|c|}{ Vegetables } & \multicolumn{3}{|c|}{ Fruits } \\
\hline Name & $\begin{array}{c}\text { Niacin } \\
\left(B_{3}\right)\end{array}$ & $\begin{array}{c}\text { Pantothenic } \\
\text { acid }\left(\mathbf{B}_{5}\right)\end{array}$ & Name & $\begin{array}{c}\text { Niacin } \\
\left(B_{3}\right)\end{array}$ & $\begin{array}{c}\text { Pantothenic } \\
\text { acid (B5) }\end{array}$ \\
\hline cabbage & 1000 & 100 & apple & 500 & 90 \\
\hline carrot & 1500 & 300 & apricot & 700 & 120 \\
\hline cauliflower & 500 & 440 & banana & 500 & 150 \\
\hline celeriac & 400 & 400 & grape & 400 & 60 \\
\hline cucumber & 100 & 120 & grapefruit & 200 & 170 \\
\hline green beans & 1000 & 470 & lemon & 100 & 200 \\
\hline green peas & 1000 & 50 & orange & 200 & 170 \\
\hline green pepper & 200 & 190 & peach & 900 & 100 \\
\hline kohlrabi & 300 & 200 & pear & 300 & 50 \\
\hline lettuce & 500 & 110 & plum & 500 & 90 \\
\hline spinach & 1000 & 110 & raspberry & 400 & 160 \\
\hline tomato & 500 & 20 & sour cherry & 300 & 80 \\
\hline water melon & 200 & 700 & strawberry & 300 & 40 \\
\hline \multicolumn{6}{|c|}{ Average content (mg) in $\mathbf{1 0 0} \mathrm{g}$ mushrooms (fresh) } \\
\hline $\begin{array}{l}\text { white } \\
\text { button } \\
\text { mushroom }\end{array}$ & 4600 & 1800 & & & \\
\hline $\begin{array}{l}\text { oyster } \\
\text { mushroom }\end{array}$ & 5200 & 500 & & & \\
\hline shiitake & 1100 & & & & \\
\hline
\end{tabular}

Vitamin $\mathbf{B}_{\mathbf{9}}$ (folic acid) is found in a number of vegetables (e.g. cabbage, carrot, kohlrabi, spinach). Folic acid is responsible for the formation of red and white blood cells in bone marrow. For instance pregnant women are encouraged to increase their folic acid intake to ensure proper foetal development.

Mushrooms contain moderately high amounts of Vitamin $\mathrm{B}_{9}$ (except oyster mushroom that is rather rich this vitamin, Table 7).
Table 7. Average folic acid content $(\mu \mathrm{g})$ in $100 \mathrm{~g}$ vegetables, fruits and mushrooms (fresh)

\begin{tabular}{|c|c|c|c|}
\hline \multicolumn{4}{|c|}{ Average content $(\mu \mathrm{g})$ in $100 \mathrm{~g}$ vegetables and fruits (fresh) } \\
\hline \multicolumn{4}{|c|}{ Folic acid } \\
\hline \multicolumn{2}{|l|}{ Vegetables } & \multicolumn{2}{|c|}{ Fruits } \\
\hline Name & & Name & \\
\hline cabbage & - & apple & 6,0 \\
\hline carrot & 6,4 & apricot & 3,0 \\
\hline cauliflower & 34,0 & banana & 13,0 \\
\hline celeriac & 4,4 & grape & 5,2 \\
\hline cucumber & 14,0 & grapefruit & 7,0 \\
\hline green beans & 41,0 & lemon & 4,0 \\
\hline green peas & 13,0 & orange & 17,0 \\
\hline green pepper & 13,0 & peach & 2,5 \\
\hline kohlrabi & - & pear & - \\
\hline lettuce & 25,0 & plum & 1,9 \\
\hline spinach & 66,0 & raspberry & - \\
\hline tomato & 37,0 & sour cherry & - \\
\hline water melon & 2,2 & strawberry & - \\
\hline \multicolumn{4}{|c|}{ Average content $(\mu \mathrm{g})$ in $100 \mathrm{~g}$ mushrooms (fresh) } \\
\hline white button mushroom & 45,0 & & \\
\hline oyster mushroom & 64,0 & & \\
\hline shiitake & 30,0 & & \\
\hline
\end{tabular}

The daily requirement of vitamin Bg for adults is $400 \mu \mathrm{g}$.

$100 \mathrm{~g}$ serving of mushrooms provides $7,5-16,0 \%$ of the recommended daily dietary intake of folic acid.

Vitamin D is a fat soluble vitamin. There are only a few natural sources of vitamin $\mathrm{D}_{2}$. It is found mostly in seafood and animal products (fish and fish liver, milk, butter and cheese), but no plant-products (fruit or vegetables) consist any of it. Therefore vegetarians, who are not consuming even milk products, are at risk of vitamin D deficiency (Jasinghe et al., 2005; Mattila et al., 2000). Different mushroom species contain distinct levels of vitamin $\mathrm{D}_{2}$ and ergosterol. We are running a number of experiments with pre-harvest Agaricus bisporus. The mushrooms are treated with UV light in order to increase vitamin $\mathrm{D}_{2}$ level. After the analysis of the first results we are planning to prepare a study about our findings.

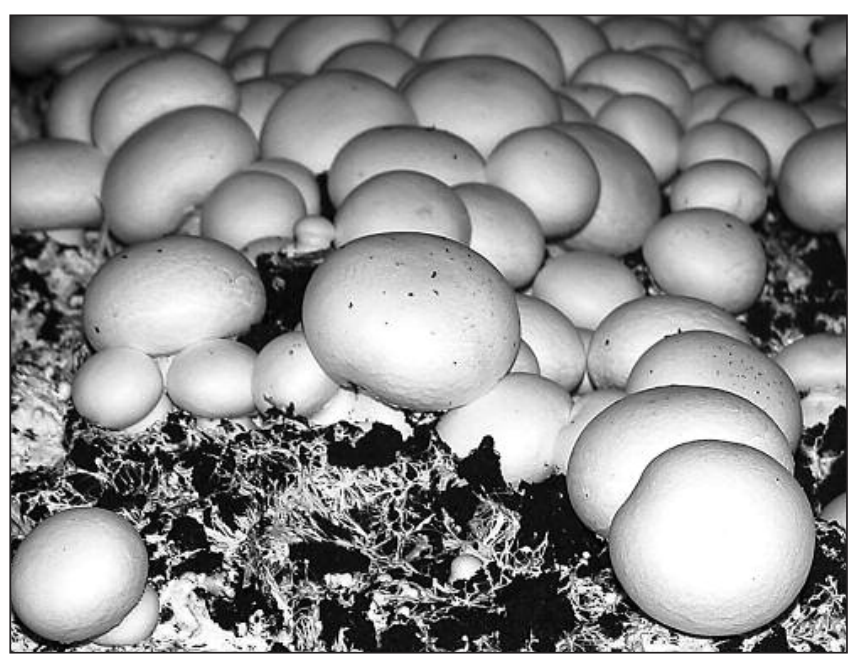

Figure 1. Fruit bodies of white button mushroom (Agaricus bisporus) 
The data presented in this paper shows that many nutritional compounds of the cultivated mushrooms are present in a significantly higher amount than in case of the most commonly consumed vegetables and fruits.

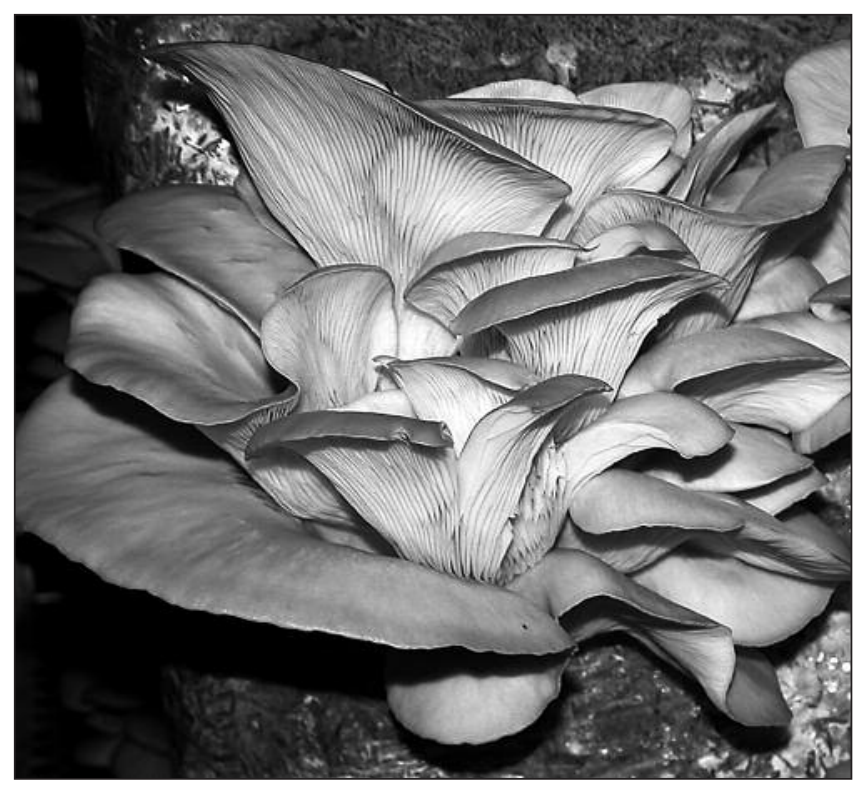

Figure 2. Oyster mushroom (Pleurotus spp.)

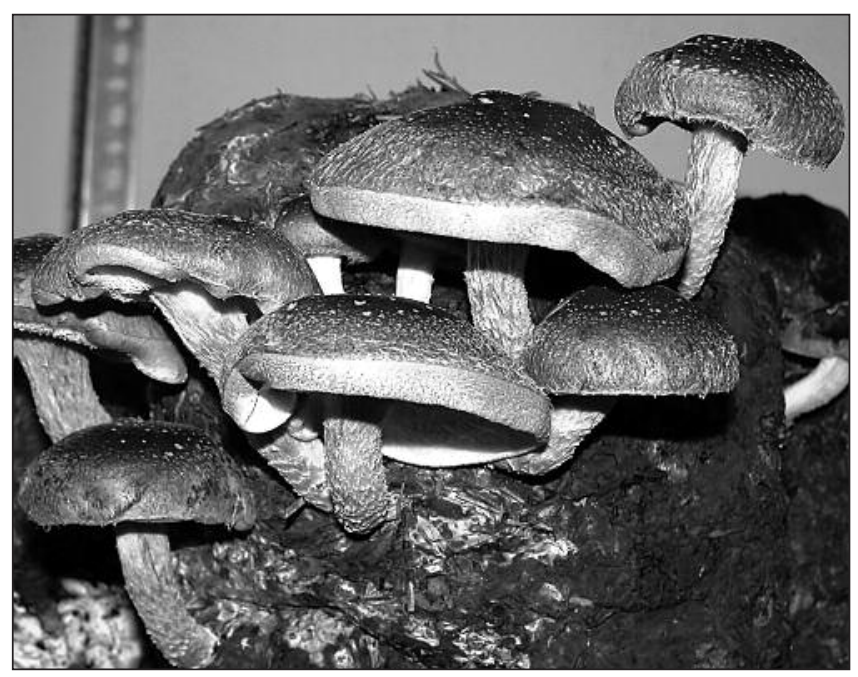

Figure 3. Shiitake (Lentinula edodes) DSCN 5162

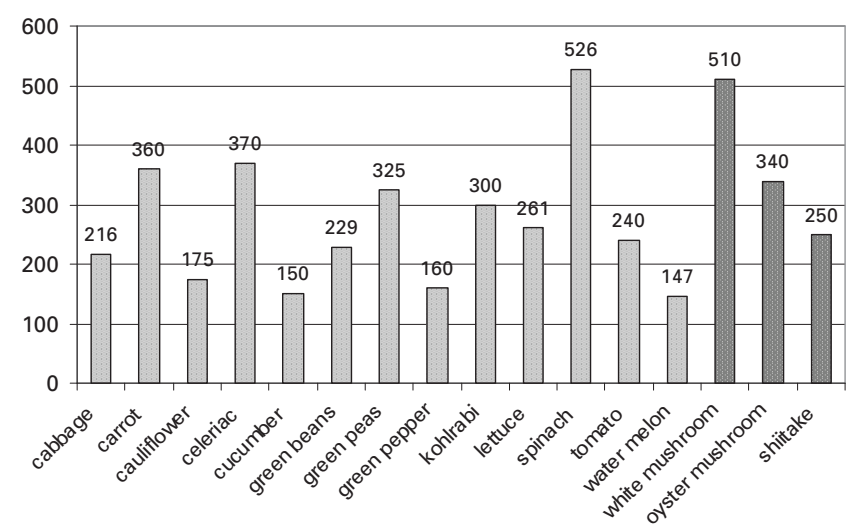

Figure 4. Average content of potassium (mg) in $100 \mathrm{~g}$ vegetables and mushrooms (fresh)

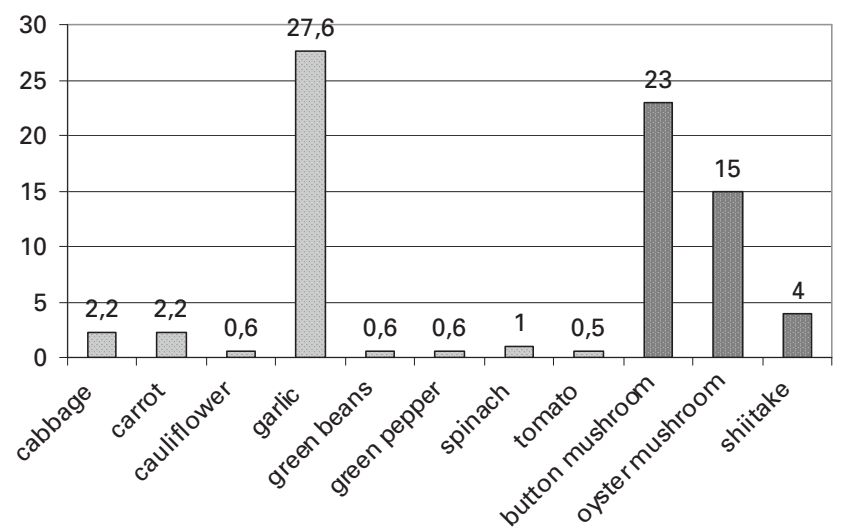

Figure 5. Average selenium content (mg) in $100 \mathrm{~g}$ vegetables and mushrooms (fresh)

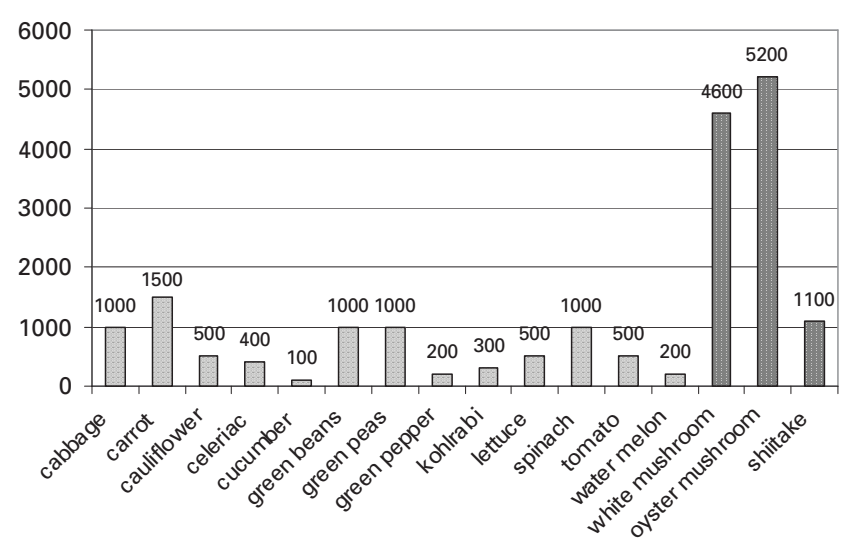

Figure 6. Average niacin content $(\mu \mathrm{g})$ in $100 \mathrm{~g}$ vegetables and mushrooms (fresh)

\section{References}

Bíró, Gy. \& Lindner, K. (szerk.)(1999): Tápanyagtáblázat. Táplálkozástan és tápanyag-összetétel. Medicina Könyvkiadó Rt, Budapest.

Bíró, Gy. (fordító) (2004): Tápanyag-beviteli referencia értékek. Medicina Könyvkiadó, Budapest.

Chang, S.T. \& Miles, P.G. (1992): Mushroom biology - a new discipline. The Mycologist, (6): 64-65.

Cheung, P.C. K. (2008): Mushrooms as functional foods. A John Wiley \& Sons, Inc. Hoboken, New Jersey, 213-215.

Fehérvári-Póczik, E., Győrfi, J., Dernovics, P., Maszlavér, P. \& Stefanovits-Bányai, É. (2005): Effect of Mushroom's Selenium supply on a few biochemical parameters. Opatija, XI. Croation Symposium on Agriculture. 333-334.

Hawksworth, D. L. (2001): The magnitude of fungal diversity: The 1,5 million species estimate revisited. Mycological Research, (105): 1422-1432.

Jasinghe, V.J., Perera, C. O. (2005): Distribution of ergosterol in different tissues of mushrooms and its effect on the conversion of ergosterol to vitamin $\mathrm{D}_{2}$ by UV irradiation. Food Chemistry, (92): 541-546.

Lelley, J., Vetter, J. (2004): Orthomolecular Medicine and Mushroom Consumption - An Attractive Aspect for Promoting Production. Mushroom Science, (16): 637-643. 
Lelley, J. \& Vetter, J. (2005): The Possible Role of Mushrooms in Maitaining Good Health and Preventing Diseases. Acta Edulis Fungi, (12). Proceedings of the Fift ${ }^{\text {th }}$ International Conference on Mushroom Biology and Mushroom Products, 412-419.

Mattila, P. H., Suonpää, K. \& Piironen, V. (2000): Functional properties of edible mushrooms. Nutrition, (16): 694-696.

Morris, V. C. \& Levander, O. A. (1970): Selenium Content of Foods. Journal of Nutrition, (100): 1383-1388.

Shimizu, T. (2003): Health claims on functional foods: The Japanese regulations and an international comparison. Nutrition Research Reviews, (16): 241-252.

Vetter, J., Hajdú, Cs., Győrfi J. \& Maszlavér, P. (2005): Mineral Composition of the Cultivated Mushrooms Agaricus bisporus,
Pleurotus ostreatus and Lentinula edodes. Acta Alimentaria, 34 (4): 441-451.

Vetter, J. \& Lelley, J. (2004): Selenium Level of the Cultivated Mushroom Agaricus bisporus. Acta Alimentaria, 33 (3): 297-301.

Vetter, J. (1990): Mineral element content of edible and poisonous macrofungi. Acta Alimentaria, (19): 27-40.

Vetter, J. (1994): Mineral elements in the important cultivated mushrooms Agaricus bisporus and Pleurotus ostreatus. Food Chemistry, (50): 277-279.

Vetter, J. (2000): Mikoterápia - a gyógyászat új lehetősége? Gyógyszerészet, 44 (89): 464-469.

www. shoppingtrolley. net/vitamin-guide. shtml. 2010.04.17. 